\title{
Material Conformity and Bactericidal Characteristics of High-Density Ozone Disinfection in Vinyl Polysiloxane Impression and PMMA Dentistry Fillings
}

\author{
Hiroshi Ohkawa1, Tetsuya Akitsu ${ }^{2}$ \\ ${ }^{1}$ Plasma Division, Yamato Science Co. Ltd., Minami-Alps City, Japan \\ ${ }^{2}$ Division of Human Environmental and Medical Engineering, Interdisciplinary Graduate School of Medicine and \\ Engineering, National University of Yamanashi, Kofu, Japan \\ Email: akitsu@yamanashi.ac.jp
}

Received 7 March 2014; revised 7 April 2014; accepted 14 April 2014

Copyright @ 2014 by authors and Scientific Research Publishing Inc.

This work is licensed under the Creative Commons Attribution International License (CC BY). http://creativecommons.org/licenses/by/4.0/

(c) $\underset{\mathrm{EY}}{\mathrm{BY}}$ Open Access

\begin{abstract}
Disinfection was investigated in high-density ozone produced by dielectric barrier discharge under atmospheric pressure. Disinfection was studied on three-dimensional carriers made of hydrophilic vinyl-polysiloxane impression material and granular acrylic resin used for oral surgery. Experimental results indicate disinfection of spore-forming bacteria: Geobacillus stearothermophilus and Bacillus atrophaeus, and selected species of opportunistic pathogens: Aspergillus niger, Pseudomonas aeruginosa, Escherichia coli, Staphylococcus aureus, and Candida albicans.
\end{abstract}

\section{Keywords}

Ozone Disinfection, Bacillus atrophaeus, Geobacillus stearothermophil, Aspergillus niger, Pseudomonas aeruginosa, Escherichia coli, Staphylococcus aureus, Candida albicans

\section{Introduction}

Advanced scheme for the sterilization and high-grade disinfections of patient-care products has been drawn attention increasingly. Increasing consideration has been required in medical institutions for nosocomial infection in patients, cross-infection among medical facilities staff, and secondary infection of immune deficient patients. This is not only due to emerging diseases such as enterohemorrhagic Escherichia coli (EHECO-157), human immunodeficiency virus (HIV), severe acute respiratory syndrome virus (SARS), and Ebora hemorrhagic fever 
but also due to the increase in infection by normal flora in the soil and human skin, such as Acinetobacter, Candida albicans, Staphylococcus aureus etc. Advanced schemes for the sterilization of medical-care materials are being increasingly drawn attention. Because of the possibility of infection by blood-originating pathogens, certain precautions are needed for handling medical-care materials, such as dental impression, as an integral part of dental practice of infection control for dental health-care personnel [1].

Infection control, using disposable patient-care products such as gloves, has certain limits. The application of on-site disinfection using certain surgery equipment and materials can reduce the risk of infection in medical treatment. In this report, we describe the study of a disinfection system using high-density ozone produced by atmospheric-pressure dielectric barrier discharges. Conventional methods for preventing infection are widely accepted. Disinfection using high-pressure steam in an autoclave, however, can introduce surface damage to metallic surgical tools and distortion of delicate plastic parts of medical-care products. For disinfection using liquid chemical agents, certain species of pathogenic bacteria acquires resistance and infection by a multiresistant pathogen is a serious biohazard. Some chemical disinfectants are also toxic. Although gas sterilization using ethyleneoxide gas (EtO) plays a primary role in low-temperature sterilization, treatment using EtO should meet rigorous protocols, because EtO is an agent that reacts with many constituents of tissue resulting in cellular and tissue dysfunctions and damages. Human carcinogenicity by EtO is a strong concern. The United States Department of Health and Human Services (DHHS) has determined that EtO may reasonably be anticipated to be a human carcinogen [2] [3].

Storage of such chemical compounds is facing increased costs and the risk of leakage in accident fears. The history of ozone disinfection begins in the 1890s. Disinfection using water-diluted ozone is a popular and reliable method for cleaning. Recent progress in ozone generation technique has enabled production of ozone in quantities as high as 50,000 to $100,000 \mathrm{ppm}$, in the semiconductor industry mask-removing process. Oxidation by high-density ozone can disinfect spore-forming bacteria. To assess the antibacterial effect, the mortality of microorganisms was examined using spore-forming bacteria: Bacillus atrophaeus (formerly Bacillus subtilis var niger) and Geobacillus stearothermophilus (formerly Bacillus stearothermophilus); a dental yeast-like fungus, Candida albicans and selected species of pathogenic bacteria, Aspergillus niger, Pseudomonas aeruginosa, Escherichia coli, and Staphylococcus aureus [4]-[8]. We reported the ozone disinfection earlier [9]-[13]. Process compatibility, however, must be checked on a case by case basis. Dental impression molds in complex shapes were made of the hydrophilic polymer used in dental surgery. The antibacterial effect varies depending on adherence strength and shape of the carrier. Impression materials for dental stone molds are complex in shape. The impression material, vinyl-polysiloxane (VPS) is flexible and has a hydrophilic surface characteristic that provides dimensional accuracy of $20 \mu \mathrm{m}$ after impression polymerization. In the sampling procedure, a small amount of saliva containing blood and dental bacteria attaches to the surface. Hydrophilic nature permits stronger microorganisms attachment. An experimental study on the disincentive characteristics of such impression material and granular bonding resin is presented herein.

\section{Experimental Procedure}

\subsection{Experimental Apparatus}

Figure 1 shows a schematic of the apparatus and time-dependent observation of ozone density during the buildup phase. The ozone density gradually accumulates to $22,500 \mathrm{ppm}$ in 80 minutes. For shorter operation times, the final density will not reach the maximum value. Final density varied depending on the wall temperature and humidity. Ozone density measurement was based on a UV absorption method (RokiTechno Co., Type ZM 20/200). The ozone generator consists of two co-planar-type discharge panels, $50 \times 100 \mathrm{~mm}$ in width and length covered with a grid of a metallic pattern with square sections $5 \times 5 \mathrm{~mm}, 17$ columns by 8 rows in a face-to-face set-up with a $17 \mathrm{~mm}$ gap, excited by $20 \mathrm{kHz}, 28 \mathrm{kV}$ peak-to-peak sinusoidal voltages. Microscopic flashover was generated from the metallic grid to a ground electrode pattern on the opposite side through the dielectric base plate. A high-density ozone mixture of 32,000 ppm was generated in oxygen (99.5\%) and supplied to the discharge region. The ozone-oxygen mixture was conducted through a Teflon-lined tube and injected through two apertures, $7 \mathrm{~mm}$ in diameter, located along the center line of the side wall.

The wall temperature was maintained at constant value with PID controlled flexible heaters to maintain the temperature in the internal space at $50^{\circ} \mathrm{C}$. Biological indicators were located at the center of the reactor, at 140 $\mathrm{mm}$ from the bottom and each corner inside. The reactor chamber dimensions were $31 \mathrm{~L}, 360 \mathrm{~mm}$ wide, 270 

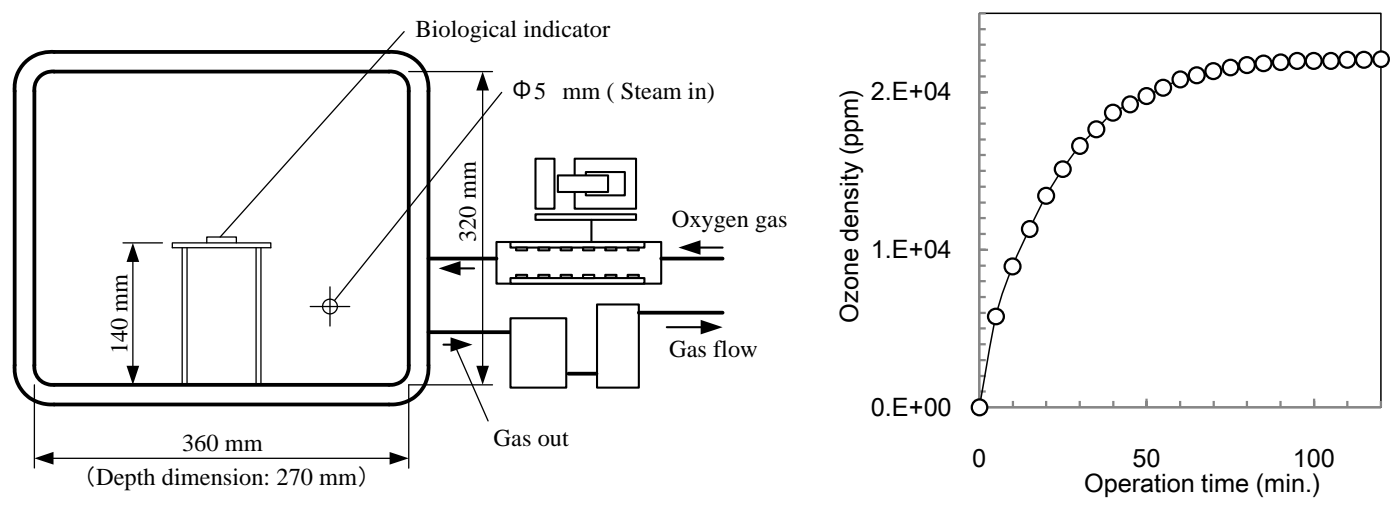

Figure 1. Ozone disinfection reactor and build up of ozone density.

$\mathrm{mm}$ deep, and $320 \mathrm{~mm}$ high, and made from aluminum with no artificially anodized coating. Steam from distilled water, $0.5 \mathrm{~mL} \cdot \mathrm{min}^{-1}$ (liquid phase), was generated in a perforated brass block, heated to $120^{\circ} \mathrm{C}$ and supplied into the reactor chamber. The relative humidity in the reactor chamber was maintained at $72 \%$. The value was determined by the condensation at the lowest temperature from the chamber wall. Ozone mixture working gas was decomposed by using a manganese peroxide-coated carbon honeycomb catalysis, and the outflow to the exterior environment was controlled to be lower than $0.05 \mathrm{ppm}$. This emission level meets the operational exposure limits in the United Kingdom, other parts of Europe, the United States, Canada, and Japan: 0.1 ppm for regular exposure. The ozone density in the exhaust gas was measured with a GASTEC absorption tube. Deterioration of plastic material was measured with IR absorption using a microscopic Fourier-Transform Infrared (FTIR) spectrometer (Jansen Microscopic-FTIR) and processed with a workstation (WS/IR-8300, Jasco Co.). Attenuated total-reflectance (ATR) data are not available for these samples.

\subsection{Test Species for Antibacterial Effect Examination}

In the first experiment, a biological indicator, made of Schleicher \& Schuell filter paper \#470, 6.4 × $38.1 \mathrm{~mm}$ in width and length, respectively, was used as a carrier for Bacillus atrophaeus ATCC 9372 spores of $2.0 \times 10^{6}$ CFU. ATCC stands for the American Type Culture Collection. CFU stands for colony-forming units, the density of active end-spores to be detected as individual colonies after incubation. Samples of microorganisms were selected from the library of the Raven Biological Laboratories Company.

Although maximum disinfection grade can be obtained with direct exposure, radicals are supplied through a small perforation of a porous sheet covering a plastic sterile casing. Thus, the compatibility study with such sterile packaging is important for use in transportation and for storage. Compatibility involves two conditions: \#1. The antibacterial effect is sufficient in the region separated by the porous sheet; \#2. The disinfection process will not deteriorate the sheet or the sterile casing. The selected package materials were polyethylene, poly(propylene), glassine paper, and a Tyvek sheet. Glassine paper is commercially available wax-applied cellophane, with small holes approximately of $1 \mu \mathrm{m}$ in size at a density of 200 holes per $1 \mathrm{~mm}^{2}$. Tyvek is a high-density polyethylene non-woven fabric of $0.15 \mathrm{~mm}$ in thickness. The density of microscopic apertures in this non-woven fabric is not identified. The selected microorganisms were spore-forming, gram-positive bacteria: Geobacillus stearothermophilus ATCC 7953, Bacillus atrophaeus ATCC 9372, and Bacillus subtilis ATCC 6653. G. stearothermophilus is approved as a standard indicator for autoclaving, which is pressurized, high-temperature steam sterilization, and B. atrophaeus is an approved indicator for gas sterilization using ethylene oxide. From a clinical view, opportunistic pathogens: Aspergillus niger ATCC 16404, Pseudomonas aeruginosa ATCC 9027, Escherichia coli JCM 1649 Staphylococcus aureus ATCC 6538, and a yeast-like fungus, Candida albicans ATCC 10231, were prepared. JCM stands for the Japan Collection of Microorganisms, a library of available microorganisms. The density of the microorganisms was adjusted in the following way. Selected species were incubated in a soybean casein digest (SCD)—fluid culture medium. A small amount of culture fluid was transferred to an SCD-agar culture medium and incubated. A small amount of the cultured sample was diluted in distilled water, and density was adjusted to approximately $10^{6} \mathrm{CFU}$ per $0.1 \mathrm{~mL}$. An amount of $0.1 \mathrm{~mL}$ of the suspension was applied to sterilized carriers and formed circular region of 8 to $10 \mathrm{~mm}$ in diameter after drying. The carrier ma- 
terials were a stainless steel plate of $15 \times 15 \mathrm{~mm}^{2}$ and $1.5 \mathrm{~mm}$ in thickness, a slide glass, a filter paper carrier, and a dental impression made of VPS. The hydrophilic surface characteristics and flexibility of VPS allow stronger attachment of microorganisms, compared with a smooth surface, such as a slide glass. The selected material is commercially available Exafine from GC Medical Corp., Japan. This material is equivalent to Ewaflex, marketed by GC America in the United States, Exafine samples were cut out into $15 \times 15 \mathrm{~mm}^{2}$ samples, including one or two impressions of teeth, Candida albicans ATCC $10231\left(2.2 \times 10^{6} \mathrm{CFU}\right)$ was applied onto the carriers. Reference biological indicators were prepared with Candida albicans applied on a stainless plate, and the sterilization time was compared. After the disinfection process, the biological indicator was incubated in 100 $\mathrm{mL}$ of soybean casein digest (SCD) — culture fluid medium. In this process, we followed protocols of Japanese Pharmacopeias [14]. Incubation temperature was $55^{\circ} \mathrm{C}$ to $60^{\circ} \mathrm{C}$ for $\mathrm{G}$. stearothermophilus, $30^{\circ} \mathrm{C}$ to $35^{\circ} \mathrm{C}$ for $B$. atrophaeus, B. subtilis, P. aeruginosa, E. coli, and S. aureus, and $25^{\circ} \mathrm{C}$ for the mold bacteria: Aspergillus niger, and the yeast-like fungus: Candida albicans. After 7 days of incubation, result of the disinfection was assessed based on the turbidity of the culture media. The culture medium remains clear if $6 \times \log _{10}$ grade sterilization was successful. Conversely, the culture media appears cloudy or muddy, if some part of the microorganisms survived exposure to the ozone. The experimental result is shown in Tables 1-5.

The final experiment involved the disinfection of dental adhesive resin contaminated with Aspergillus niger and Candida albicans. The selected material was Superbond C \& B from SunMedical Co. in Japan. This compound is equivalent to C \& B-Metabondfrom Porkell Inc., marketed in North America. Super bond C \& B is a selfcuring dental adhesive system containing granular poly (methyl methacrylate) (PMMA) resin and a liquid: 5\%

\begin{tabular}{ccccccc} 
Table 1. Variation of sterilization efficiency: dependence on packaging materials. \\
\hline Material & Temperature & Thickness & \multicolumn{5}{c}{ Exposure time (min) } \\
\hline Glassine & & $(\mathrm{mm})$ & 30 & 60 & 90 & 120 \\
& 30 & 0.05 & + & + & + & - \\
& 50 & 0.05 & + & + & + & - \\
Tyvek & 70 & 0.05 & + & + & - & \\
& 30 & 0.15 & & - & - & - \\
& 50 & 0.15 & + & - & - & - \\
& 70 & 0.15 & + & - & - & \\
\hline
\end{tabular}

Biological indicator: B. atrophaeus ATCC $9372\left(2.0 \times 10^{6} \mathrm{CFU}\right)$.

Table 2. Sterilization of spore forming bacteria in Tyvek package.

\begin{tabular}{cccccc}
\hline Selected species and populations & \multicolumn{5}{c}{ Exposure time (min) } \\
\cline { 2 - 4 } G. stearothermophilus ATCC $7953\left(1.76 \times 10^{5} \mathrm{CFU}\right)$ & & + & + & - \\
B. atrophaeus ATCC $9372\left(8.48 \times 10^{5} \mathrm{CFU}\right)$ & + & + & - & \\
B. subtilis ATCC $6633\left(1.58 \times 10^{6} \mathrm{CFU}\right)$ & + & + & - \\
\hline
\end{tabular}

Table 3. Variation of sterilization efficiency: dependence on carrier material.

\begin{tabular}{cc}
\hline Carrier material $^{\mathrm{b}}$ & Result \\
\hline Stainless steel (SUS304) & ++ \\
Pyrex glass $(0.18 \mathrm{~mm})$ & -- \\
Filter paper & -- \\
\hline
\end{tabular}

${ }^{\mathrm{b}}$ Biological indicator: B. atrophaeus ATCC $9372\left(8.48 \times 10^{5} \mathrm{CFU}\right)$. 
Table 4. Sterilization in ozone mixture at $180 \mathrm{~g} / \mathrm{Nm}^{3}$. (a) Sterilization of commercial biological indicators; (b) Effect on packaging material, humidity 100\%; (c) Effect on packaging material, temperature, humidity $100 \%$.

(a)

\begin{tabular}{|c|c|c|c|c|c|}
\hline \multirow{2}{*}{3 M Attest R 1264/1262 } & \multirow{2}{*}{$\begin{array}{l}\text { Humidity } \\
\text { At } 50^{\circ} \mathrm{C}\end{array}$} & \multicolumn{4}{|c|}{ Exposure time (min) } \\
\hline & & 15 & 20 & 25 & 30 \\
\hline B. atrophaeus (Attest ${ }^{\mathrm{TM}} 1264$ ) & $100 \%$ & + & + & + & - \\
\hline G. stearothermophilus (Attest ${ }^{\mathrm{TM}} 1262$ ) & $100 \%$ & + & + & - & - \\
\hline
\end{tabular}

(b)

\begin{tabular}{cccc}
\hline Biological indicator & Package type & \multicolumn{2}{c}{ Exposure time (min) } \\
\cline { 2 - 3 } B. atrophaeus & At $50^{\circ} \mathrm{C}$ & 30 & 45 \\
ATCC $9372\left(1.0 \times 10^{6} \mathrm{CFU}\right)$ & Tyvek package & - & - \\
G. stearothermophilus ATCC $7953\left(1.3 \times 10^{6} \mathrm{CFU}\right)$ & Glassine & Tyvek package & - \\
\hline
\end{tabular}

${ }^{\mathrm{c}}$ Damage of bonding observed.

(c)

\begin{tabular}{ccccc}
\hline Biological indicator & Temperature & \multicolumn{3}{c}{ Exposure time (min) } \\
\cline { 2 - 5 } & ${ }^{\circ} \mathrm{C}$ & 5 & 10 & 15 \\
B. atrophaeus & 50 & + & - & - \\
ATCC $9372\left(1.0 \times 10^{6} \mathrm{CFU}\right)$ & 65 & - & $--^{\mathrm{d}}$ \\
\hline
\end{tabular}

${ }^{\mathrm{d}}$ Damage of non-woven sheet observed.

Table 5. Disinfection of opportunistic pathogen in Tyvek package.

\begin{tabular}{cccc}
\hline Biological indicator and population & \multicolumn{3}{c}{ Exposure time (min) } \\
\cline { 2 - 3 } Aspergillus niger ATCC $16404\left(7.83 \times 10^{5} \mathrm{CFU}\right)$ & 10 & 20 & - \\
Pseudomonas aeruginosa ATCC $9027\left(3.36 \times 10^{6} \mathrm{CFU}\right)$ & - & - & - \\
Escherichia coli JCM1649 $\left(1 \times 10^{6} \mathrm{CFU}\right)$ & - & - & - \\
Staphylococcus aureus ATCC $6538\left(5.48 \times 10^{6} \mathrm{CFU}\right)$ & - & - & - \\
Candida albicans ATCC $10231\left(1.32 \times 10^{6} \mathrm{CFU}\right)$ & - & - & - \\
\hline
\end{tabular}

4-META/95\% MMA-TBB. MMA is methyl methacrylate monomer, 4-META 4-methacryloxyethyl trimellitate anhydride, and TBB: tributyl-borane hardening catalyst. This material is applied in oral surgery as a coating and teeth adhesive (enamel and dentin), metallic parts and dental resin.

\section{Experimental Results}

\subsection{Disinfection of Standard Spore Forming Bacteria in Sterile Packages}

The experimental result is summarized as following tables. In the tables “-” minus indicates the successful disinfection and “+” plus indicates a denial of sterility. Table 1 show the results of spore-forming bacteria, Bacillus atrophaeus, on a filter paper carrier and wrapped in sterile packages. Glassine paper required 120 min exposure, while the Tyvek package required 60 min for disinfection, showing the present scheme to be compatible with Tyvek packages. This experiment was conducted at different temperatures of $30^{\circ} \mathrm{C}, 50^{\circ} \mathrm{C}$ and $70^{\circ} \mathrm{C}$. In the case of Glassine paper, sterilization time was shorter at higher temperatures. In Tyvek packages, no significant influ- 
ence from temperature was observed. Table 2 shows a comparison of disinfection times for spore-forming bacteria: Geobacillus stearothermophilus, Bacillus atrophaeus, and Bacillus subtilis. Sterilization of these sporeforming bacteria required rather long period of 90 to 120 minutes. Table 3 shows the dependence of sterilization time on carrier material. Although Bacillus atrophaeus was sterilized on glass plate or filter paper carrier, the biological indicator on stainless steel carrier was positive. Probably, the iron site on the carrier acts as quencher of ozone.

In the next experiment, higher density was realized using a small reactor made of acrylic-Lucite with $40 \mathrm{~mm}$ internal diameter. Table 4 shows the result of disinfection experiment using high density ozone at $180 \mathrm{~g} / \mathrm{Nm}^{3}$, i.e., 84,000 (ppm). In Table 4(a), wall temperature was raised to $50^{\circ} \mathrm{C}$ and humidity $100 \%$. Two biological indicators of 3 M Attest ${ }^{\mathrm{TM}} 1262$ and Attest ${ }^{\mathrm{TM}} 1264$, containing Bacillus atrophaeus $3.9 \times 10^{6} \mathrm{CFU}$ with approved EOG kill time $31.77 \mathrm{~min}$ and Geobacillus stearothermophilus $5.7 \times 10^{5} \mathrm{CFU}$ were disinfected in the original plastic sterile capsules within 30 minutes. Table 4(b) shows the result of experiment using biological indicators enclosed in Glassine and Tyvek sterile packages. Although the disinfection was completed in 30 minutes, glassine package was broken at the corner. In this case, glassine sheet is not appropriate for the sterility package for use as a sterile package for ozone/vapor disinfection. Table 4(c) shows the result of experiment at $65^{\circ} \mathrm{C}$. In this experiment, some deterioration of non-woven sheet was observed in 10 minutes, whereas such deterioration was not observed at $50^{\circ} \mathrm{C}$. Thus, $50^{\circ} \mathrm{C}$ is the appropriate working temperature for the practical use of ozone disinfection system. Although higher disinfection efficiency can be realized at higher wall temperatures, at $65^{\circ} \mathrm{C}$, deterioration of sterile package may cause possible denial of sterility assurance.

\subsection{Disinfection of Opportunistic Pathogenic Microorganism}

Table 5 shows the result of disinfection for opportunistic pathogens, Aspergillus niger, Pseudomonas aeruginosa, Escherichia coli, Staphylococcus aureus and Candida albicans. This result indicates that these pathogenic species can be disinfected in sterile packages. Figure 2 shows control showing turbidity and clear samples indicating the disinfection, from left to right: control, exposed samples for 10, 20, and 30 minutes.

\subsection{Disinfection of Impression Material and Granular Acrylic Resin Filler}

Figure 3 shows a VPS dental impression and acryl-resin for filler for rebuilding the tooth surf. Table 6 shows a result of the disinfection experiment of Candida albicans applied to smooth stainless steel and shaped Exafine tooth impression. Figure 4, for example, shows the typical result of incubation (from left to right): an untreated control, the second and the third containers show positive results, while the fourth and fifth containers are clear indicating negative result (-). Candida albicans samples applied to impression material located at the position in the reactor and locations indicated in Figure 5. Table 7 shows the results of this experiment. 15 minutes of exposure and short aeration time are sufficient for complete disinfection.

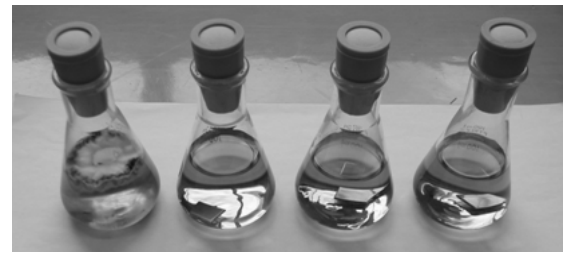

(a)

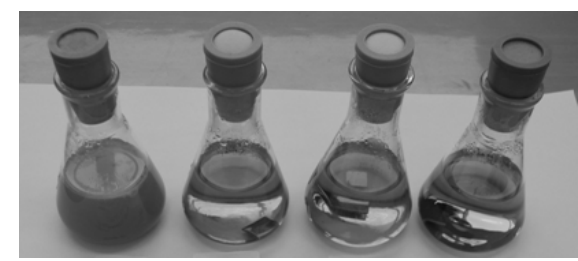

(b)

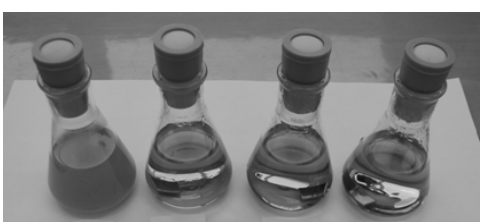

(c)

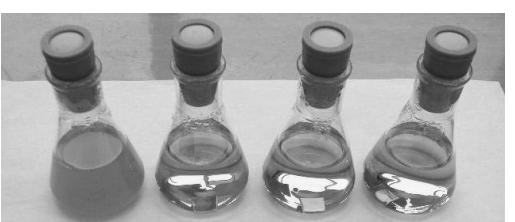

(d)

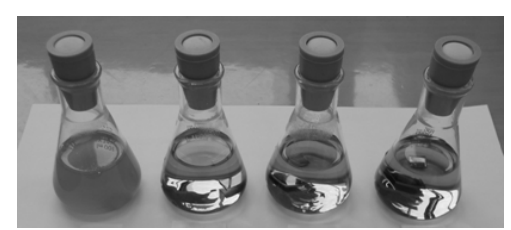

(e)

Figure 2. Disinfection of opportunistic pathogen in Tyvek package. (a) Aspergilles niger ATCC 16404 (7.83 × $\left.10^{5} \mathrm{CF}\right)$; (b) Popsuedomonas aeruginosa ATCC 9027 (3.36 × $10^{6}$ CFU); (c) Escherichia coli JCM1649 (1 × $10^{6}$ CFU); (d) Staphylococcus aureus ATCC 6538 (5.48 × 106 CFU); (e) Candida albicans ATCC 10231 (1.32 × 10 CFU). 

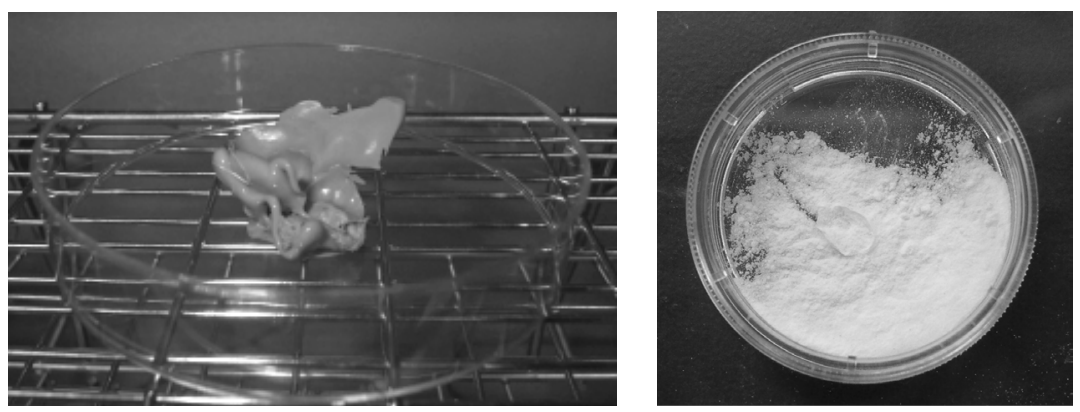

Figure 3. Exafine VPS tooth impression and acryl resin for filler.

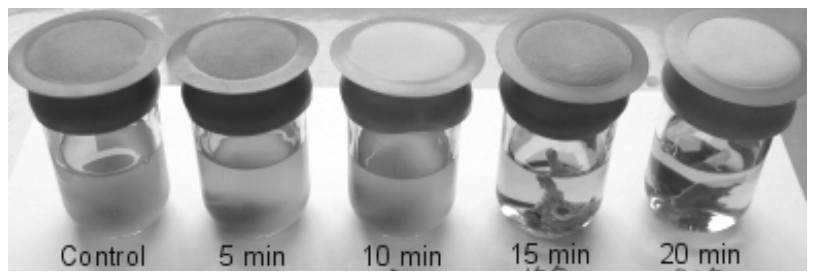

Figure 4. Disinfection of Candida albicans applied to Exafine.

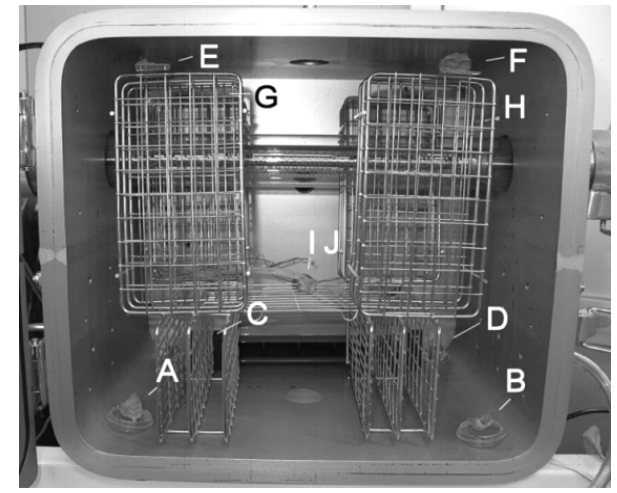

Figure 5. Disinfection of Candida albicans in ozone reactor: location of biological indicator A to J.

Table 6. Disinfection of Candida albocans applied to Exafine impression material.

\begin{tabular}{cccccc}
\hline Carrier and population & \multicolumn{5}{c}{ Exposure time (min) } \\
\cline { 2 - 5 } Stainless steel $\left(1.32 \times 10^{6} \mathrm{CFU}\right)$ & 5 & 10 & 15 & 20 & 30 \\
Exafine $\left(1.43 \times 10^{6} \mathrm{CFU}\right)$ & & - & - & - \\
\hline
\end{tabular}

Biological indicator: Candida albicans ATCC 10231.

Table 7. Disinfection of Candida albicans applied to Exafine impression material in an ozone reactor.

\begin{tabular}{cccccccccccccc}
\hline & \multicolumn{10}{c}{ Position of indicator $^{\mathrm{a}}$} \\
\cline { 2 - 10 } & Axposure time (min) & B & C & D & E & F & G & H & I & J \\
\hline 15 & - & - & - & - & - & - & - & - & - & - \\
30 & - & - & - & - & - & - & - & - & - & - \\
\hline
\end{tabular}

${ }^{\mathrm{a} B i o l o g i c a l ~ i n d i c a t o r: ~ C a n d i d a ~ a l b i c a n s ~ A T C C ~} 10231$ (1.4 × $10^{6}$ CFU). 
Next, we show the disinfection of Aspergillus niger in granular acrylic resin. A PMMA resin of $0.16 \mathrm{~g}$ was measured with a small-sized measuring spoon and placed in a small petridish, and a distilled water suspension of Aspergillus niger was applied. The final population was adjusted to be approximately to $3.4 \times 10^{5} \mathrm{CFU}$. Similar experiment was repeated for Candida albicans $\left(1.7 \times 10^{6} \mathrm{CFU}\right)$ sample. The top of acryl resin shows more like solid shell than granular resin. After the disinfection cycle, whole resin samples were incubated in an SCD fluid culture medium. The incubation result shows that disinfection was completed in 10 and 15 minutes, without significant deterioration in solidity when mixed PMMA resin was formed. The results are summarized in Table 8. FTIR spectra were measured for a sliced sample of Exafine.

\section{Discussion}

Table 9 shows the antibacterial spectrum of the present scheme, covering Gram-stain-positive bacteria, Gramstain-negative bacteria, yeast, and mold. The sterilization time was compared for Candida albicans, in a series of plain and shaped Exafine carrier and composite Exafine carrier with narrow gaps. The following bactericidal effect was observed inside sterile packages of a Tyvek. Although opportunistic pathogenic bacteria were sterilized within short time, inactivation of spore-forming bacteria of Bacillus genera required longer time. Experimental results indicate that mixing with water vapor is essential. This result suggests speculation for the mechanism of disinfection based on hydroxyl radicals generated in reactions.

Decomposition of ozone: $\mathrm{O}_{3} \rightarrow \mathrm{O}_{2}+\mathrm{O}\left({ }^{1} \mathrm{D}\right)$

Production of hydroxyl radical: $\mathrm{H}_{2} \mathrm{O}+\mathrm{O}\left({ }^{1} \mathrm{D}\right) \rightarrow \mathrm{OH} \cdot+\mathrm{OH}$.

Vapor injection plays an essential part; injection of dry ozone was tested and was shown to require an operational time for sterilization of twice that or longer than the values measured here. Low-temperature vapor itself is also ineffective. The measured incompatibility in package materials of polyethylene and poly (propylene) indicates that discretion is needed in the package material selection. A porous sheet must be used for ozone disinfection. Figure 6 shows the FTIR results for an untreated control and the treated sample. The experiment shows no significant change, such as oxidation. In this experiment, FTIR observation indicated no positive evidence for the deterioration in the surface of silicone compound used for tooth profile impression or in polymer resin powders. Polymer conformity must be investigated case by case in the future applications. Table 10 shows known conformities between solid materials and ozone treatment.

A grading system set forth by Ozonesolutions Co. [15] is based on the following criteria: A means excellent conformity. Ozone has no effect on these materials. B means good conformity. Ozone has a minor effect on these materials. Prolonged use, however, will breakdown or corrode these materials with high concentrations of ozone. C means fair conformity. Exposures to ozone will breakdown these materials within several weeks of use. D means poor or very poor conformity. Exposures to ozone will breakdown these materials within several days or even hours of use. Carbon steel shows poor conformity to advanced oxidation process [16]. Materials like EPDM show higher degradation in exposure to wet ozone compared to dry ozone. In the degradation process of

Table 8. Disinfection of granular acrylic resin contaminated.

\begin{tabular}{ccc}
\hline Biological indicator and population & \multicolumn{2}{c}{ Exposure time (min) } \\
\cline { 2 - 3 } & 10 & - \\
\hline Aspergillus niger ATCC $16404\left(3.4 \times 10^{5} \mathrm{CFU}\right)$ & - & - \\
\hline Candida albicans ATCC $10231\left(1.7 \times 10^{6} \mathrm{CFU}\right)$ & - & - \\
\hline
\end{tabular}

Table 9. Antibacterial effect.

\begin{tabular}{ccc}
\hline & Microorganism & \\
\hline Gram-stain positive & Gram-stain negative & Yeast/Fungus \\
S. aureus & E. coli, P. aeruginosa & C. albican, A. niger \\
Disinfected & Disinfected & Disinfected \\
\hline
\end{tabular}




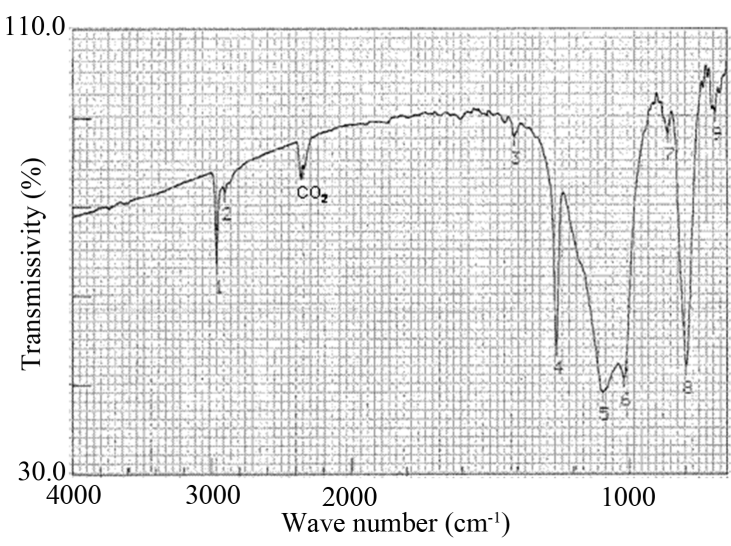

(a)

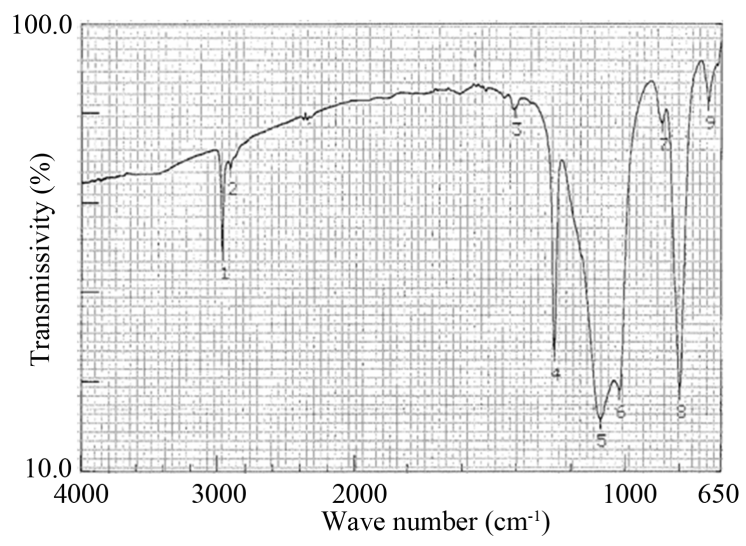

(b)

Figure 6. FTIR for control and treated samples. (a) FTIR of untreated control; (b) FTIR of treated material.

Table 10. Conformity grade of solid materials.

\begin{tabular}{|c|c|}
\hline \multirow{2}{*}{$\begin{array}{l}\text { Conformity } \\
\text { Grade }\end{array}$} & Material \\
\hline & (Alphabetical Order) \\
\hline A Excellent & $\begin{array}{l}\text { Butyl, Chemraz (Perfluoro Elastomer), CPVC (Chlorinated Polyvinyl Chloride), Cross-Linked Polyethylene (PEX), } \\
\text { Durachlor-51, EPR, Ethylene-Propylene, Vinyl-Polysiloxane Exafine, Fluorosilicone, Glass, Hastelloy-C, HDPE } \\
\text { (High-Density Polyethylene), Inconel, Kalrez, Kel-F, (PCTFE), Kynar, Millable (Polyurethane Rubber, Heat Cured } \\
\text { Rubber, Heat Vulcanized Rubber), PEEK (Polyether Ether Ketone), Polycarbonate, Poly(Methyl Methacrylate) (PMMA) } \\
\text { Resin, PVC, PVDF (Polyviniliden Fluoride), Santoprene (Thermoplastic Vulcanizates), Silicone, Stainless Steel 304/316, } \\
\text { Teflon (Polytetrafluoroethylene), Titanium, Vamac (Ethylene Acrylic Elastomer), Viton (Fluoropolymer Elastomer) }\end{array}$ \\
\hline B Good & $\begin{array}{c}\text { ABS Plastic, Aluminum (Dry Ozone), Brass, Bronze, Copper, EPDM (Ethylene Propylene Diene Monomer Rubber), } \\
\text { Flexelene (Polyolefin), LDPE (Low-Density Polyethylene), Polyacrylate, Polyethelyne, Polysulfide, Polyacrylate, } \\
\text { Stainless Steel (Other Grades), Tygon, Tyvek }\end{array}$ \\
\hline C Fair & $\begin{array}{l}\text { Acetal (Delrin), Aluminum (Wet Ozone), Cast Iron, Galvanized Steel, Hypalon, } \\
\text { Hytrel, Monel, Neoprene, Polyamide (PA), Polypropylene }\end{array}$ \\
\hline $\begin{array}{l}\text { D Poor or } \\
\text { Very Poor }\end{array}$ & $\begin{array}{l}\text { Buna-N (Nitrile), Magnesium, Natural Rubber (Very Poor), } \\
\text { Nylon (Very Poor), Steel (Carbon, Mild) (Very Poor), Zinc and Zinc Alloy }\end{array}$ \\
\hline
\end{tabular}

EPDM, an oxidation process produces a reduction in molecule size, which generated hydroxyl and carbonyl group [17]. Some cautions are required in the future applications. Tyvek sheet is classified to lower grade B, because deterioration in the strength was observed in the wet ozone treatment.

\section{Concluding Remarks}

A disinfection system has been developed using a discharge-based ozone generator. The antibacterial effect was investigated using biological indicators of Gram-stain-positive spore-forming bacteria, Geobacillus stearothermophilus, Bacillus atrophaeus, and Bacillus subtilis; Gram-stain positive bacteria, Staphylococcus aureus, Gram-stain negative bacteria, Pseudomonas aeruginosa and Escherichia coli, the fungi, Aspergillus niger and the yeast, Candida albicans. Disinfection by ozone mixture showed satisfactory results for standard levels of cleanliness, excluding spore-forming bacteria. The sterilization of spore-forming bacteria varied up to a relatively long processing time up to 120 minutes, depending on conditions. In this case, the disinfection system does not meet the standard for the Sterility Assurance Level $6 \times \log _{10}$ reduction of microorganisms in a limited time period. Efforts are being made to increase the efficiency of the ozone generator to realize processing in a shorter period. The disinfection efficiency is satisfactory for the carrier and adherent microorganisms in sterile packages. Convex and irregularly shaped carrier in the form of the hydrophilic vinyl polysiloxane impression material Exafine and granular acrylic resin can be disinfected. The ozone disinfection system satisfies the requirement for short exposure time and control of the sterility level in medical applications, meeting the need for a more rapid, less damaging, and sterile method. 


\section{Acknowledgements}

We acknowledge Mr. Keisuke Ohnishi, Dr. Masao Tsuji and Professor Dr. Masatoshi Ohnishi for collaboration in this experiment. The present work was supported by the Grant-in-Aid for the Development of Innovative Technology (GADIT) 2001-2003, by the Ministry of Education, Science and Culture, Japan.

\section{References}

[1] Kohn, W.G., Collins, A.S., Cleaveland, J.L., Harte, J.A., Eklund, K.J. and Malvitz, D.M. (2003) Guidelines for Infection Control in Dental Health-Care Settings-2003. Morbidity and Mortality Weekly Report (MMWR), 52, 1-61.

[2] Agency for Toxic Substances and Disease Registry (ATSDR) (2003) Medical Management Guidelines (MMGs) for Ethylene Oxide $\left(\left[\mathrm{CH}_{2}\right]_{2} \mathrm{O}\right)$. CAS 75-21-8, UN\#1040.

[3] Ethylene Oxide (EtO) DHHS (1981) Current Intelligence Bulletin 35. Publication No. 81-130.

[4] Jawetz, E., Melnick, J.L. and Adelberg, E.A. (1989) Review of Medical Microbiology. 18th Edition, Lange Maruzen, Tokyo.

[5] Levison, W. and Jawetz, E. (2002) Medical Microbiology \& Immunology: Examination \& Board Review. 7th Edition, Lange Medical Book, New York.

[6] Holt, J.G. (1986) Bergey’s Manual of Systematic Bacteriology. Williams \& Wilkins, Baltimore, 1130-1135.

[7] Nazina, T.N., Tourova, T.P., Poltaraus, A.B., Novikova, E.V., Grigoryan, A.A., Ivanova, A.E., Lysenka, A.M., Petrunyaka, V.V., Osipov, G.A., Belyaev, S.S. and Ivanov, M.V. (2001) Taxinomic Study of Aerobic Thermophillus Bacilli: Descriptions of Geobacillus subterraneus gen. nov., sp. nov., and Geobacillusuzenensis sp. nov. from Petroleum Reservoirs and Transfer of Bacillus stearothermophilus, Bacillus thercatenulatus, Bacillus thermoleovorans, Bacillus kaustophilus, Bacillus thermoglucosidasius and Bacillus thermodenitrificans to Geobacillus as the New Combinations G. stearothermophilus, G. thermocatenulatus, G. thermoleovorans, G. kaustophilus, G. thermoglucosodasius and G. thermodenitrificans. International Journal of Systematic and Evolutionary Microbiology, 51, 433-446.

[8] Dwyer, C.R. (2002) Regarding Changes to Taxonomy of Bacillus Organisms. Technical Notice, Raven Biological Laboratories.

[9] Ohkawa, H., Akitsu, T., Ohnishi, M. and Tsuji, M. (2003) High Grade Disinfection Using High Density Ozone. Proceedings of the 3rd International Symposium on the Basis and Application of Plasma Technology: APSPT 2003, Tao Yuan, 15-17 December 2003, 38.

[10] Ohkawa, H., Tsuji, M., Ohtsuki, K., Ohnishi, M. and Akitsu, T. (2005) High Density Ozone Disinfection of Medical-Care Materials for Dental Surgery. Plasma Processes and Polymers, 2, 112-119. http://dx.doi.org/10.1002/ppap.200400032

[11] Tsuji, M., Kimura, H., Akitsu, T. and Fukushima, K. (2003) Study on Plasma Sterilization under Environmental Circulation. Proceedings of the 50th Meeting of the Japan Society for Food Science and Technology.

[12] Tsuji, T., Kimura, H., Akitsu, T. and Fukushima, K. (2003) Study on Plasma Sterilization under Environmental Circulation. Report of the Yamanashi Industrial Technology Center, 9-14. (in Japanese)

[13] Fukushima, K., Akitsu, T., Fujii, K., Ohkawa, H. and Sugimoto, H. (2005) Japan Patent No. 3704129.

[14] Pharmaceuticals and Medical Devices Agency (2001) Japanese Pharmacopeias. 14th Edition, Tokyo.

[15] Ozone Solutions. https://www.ozonesolutions.com

[16] Zaaba, S.K., Akitsu, T., Ohkawa, H., Katayama-Hirayama, K., Tsuji, M., Shimizu, N. and Imanishi, Y. (2010) Plasma Disinfection and the Deterioration of Surgical Tools at Atmospheric Pressure Plasma. IEEJ Transactions on Fundamentals and Materials, 130, 355-361. http://dx.doi.org/10.1541/ieejfms.130.355

[17] Miwa, S., Kondo, H., Onitsuka, H. and Ohtake, Y. (2008) Characteristics of Vulcanized EPDM Degradation in Ozone Water or Ozone/Chlorine Water. Nippon Gomu Kyokaishi, 81, 14-18. http://dx.doi.org/10.2324/gomu.81.14 